\title{
Morphometric Study of the Nutrient Foramina of Human Femora and its Surgical Significance
}

\author{
V. Sailakumari ${ }^{1}$, G. Manoj Kumar Reddy ${ }^{2 *}$ and S. Lokanadham ${ }^{3}$ \\ ${ }^{1}$ Professor, Department of Anatomy, Santhiram Medical College and Hospital, Nandyal, Andhrapradesh-518501, India \\ ${ }^{2}$ Assistant Professor, Department of Anatomy, Rajiv Gandhi Institute of Medical Sciences, Kadapa, Andhrapradesh-518501, India \\ ${ }^{3}$ Associate Professor, Department of Anatomy, Santhiram Medical College and Hospital, Nandyal, Andhrapradesh-518501, India
}

\begin{abstract}
DOI: $10.36348 /$ sijap.2019.v02i11.008
| Received: 19.11.2019| Accepted: 26.11.2019| Published: 30.11.2019
\end{abstract}

*Corresponding author: Dr. Manoj Kumar Reddy

\section{Abstract}

Background: The major source of blood supply to long bones is by nutrient arteries in phases of ossification as well as during growth period Aim: to study the nutrient foramina of human femora and its surgical significance. Materials and Methods: 114 Dry femora (Right: 58, Left: 56) were collected from under graduate medical students and from the Department of Anatomy, Kurnool Medical College, Andhra Pradesh to study the morphometry of the nutrient foramina of human femora and its surgical significance. All the femur bones observed for number of nutrient foramen (NF) and location of nutrient foramen in the present study. The total length of each bone and distance of nutrient foramen from the proximal end of the bone was measured by using Osteometric board. Results: We noted 56 bones with single nutrient foramen on right femur bones, 2 bones noted with double nutrient foramen and also noted 55 bones with nutrient foramen on its linea aspera, 3 bones with nutrient foramen on its lateral surface out of 58 right femur bones in the present study. We noted 53 bones with single nutrient foramen on left femur bones, 3 bones noted with double nutrient foramen and also noted 52 bones with nutrient foramen on its linea aspera, 3 bones with nutrient foramen on its lateral surface, 1 bone with nutrient foramen on its medial surface out of 56 left femur bones in the present study. Conclusion: Variations in nutrient foramina is of great importance in understanding the blood supply of the femur bone for surgical procedures.

Keywords: Femur, linea aspera, nutrient foramen.

Copyright @ 2019: This is an open-access article distributed under the terms of the Creative Commons Attribution license which permits unrestricted
use, distribution, and reproduction in any medium for non-commercial use (NonCommercial, or CC-BY-NC) provided the original author and source
are credited.
are credited.

\section{INTRODUCTION}

The Femur bone is a highly vascular structure with unique features in its blood supply [1]. Blood supply to the long bones in Human body is by nutrient arteries, eipiphyseal arteries, metaphyseal arteries and periosteal arteries. Nutrient arteries play a significant role in blood supply of long bone inner $2 / 3$ rd of cortex and whole medulla of the diaphysis. The entry of nutrient artery (NA) into the Long bone is indicated as the nutrient foramen (NF). The direction of NF usually towards the elbow and away from the knee in the upper and lower limbs [2]. The nutrient artery to femur is a branch of profunda femoris artery of femoral artery. The nutrient foramen of femur is single, located on the Linea aspera on posterior surface near the proximal end of the bone and directed upwards [3]. Sometimes, more than one nutrient foramina and the nutrient foramen found on the lateral or medial surface of the shaft of the femur $[4,5]$. The present study was aimed to determine the location and number of nutrient foramina of human femora and their surgical significance.

\section{MATERIALS AND METHODS}

A total of 114 Dry femora (Right: 58, Left: 56) were collected from under graduate medical students and from the Department of Anatomy, Kurnool Medical College, Andhra Pradesh to study the morphometry of the nutrient foramina of human femora and its surgical significance. All the femur bones observed for number of nutrient foramen (NF) and location of nutrient foramen in the present study. The total length of each bone and distance of nutrient foramen from the proximal end of the bone was measured by using Osteometric board. The Femoral Index (FI) was calculated using HUGH'S Formula and the results were tabulated (Table-1). 
Table-1: Incidence of nutrient foramina on femur

\begin{tabular}{|l|l|l|l|l|l|l|l|l|}
\hline $\begin{array}{l}\text { Side of the } \\
\text { Femur }\end{array}$ & $\begin{array}{l}\text { No. } \\
\text { Bones }\end{array}$ & Single NF & $\begin{array}{l}\text { Double } \\
\text { NF }\end{array}$ & NF on LA & $\begin{array}{l}\text { NF on } \\
\text { LS }\end{array}$ & $\begin{array}{l}\text { NF } \\
\text { MS }\end{array}$ & $\begin{array}{l}\text { Mean Femoral } \\
\text { Index }\end{array}$ \\
\hline Right & 58 & $56(96 \%)$ & $02(4 \%)$ & $55(94 \%)$ & $03(6 \%)$ & 0 & 43.2 \\
\hline Left & 56 & $53(95 \%)$ & $3(5 \%)$ & $52(93 \%)$ & $03(6 \%)$ & 1 & 44.5 \\
\hline Total & 114 & $109(95.6 \%)$ & $05(4.38 \%)$ & $107(93.8 \%)$ & $06(5.6 \%)$ & 1 & 87.7 \\
\hline
\end{tabular}

NF: Nutrient Foramina; LA: Linea Aspera; LS: lateral Surface; MS: Medial Surface

\section{RESULTS}

In the present study, we selected 114 dry femur bones of both sexes to study the nutrient foramen and its morphological variations (Figure-1). We noted 56 bones with single nutrient foramen on right femur bones, 2 bones noted with double nutrient foramen (Figure-2) and also noted 55 bones with nutrient foramen on its linea aspera (Figure-3), 3 bones with nutrient foramen on its lateral surface out of 58 right femur bones in the present study. We noted 53 bones with single nutrient foramen on left femur bones, 3 bones noted with double nutrient foramen and also noted 52 bones with nutrient foramen on its linea aspera, 3 bones with nutrient foramen on its lateral surface (Figure-4), 1 bone with nutrient foramen on its medial surface (Figure-5) out of 56 left femur bones in the present study.

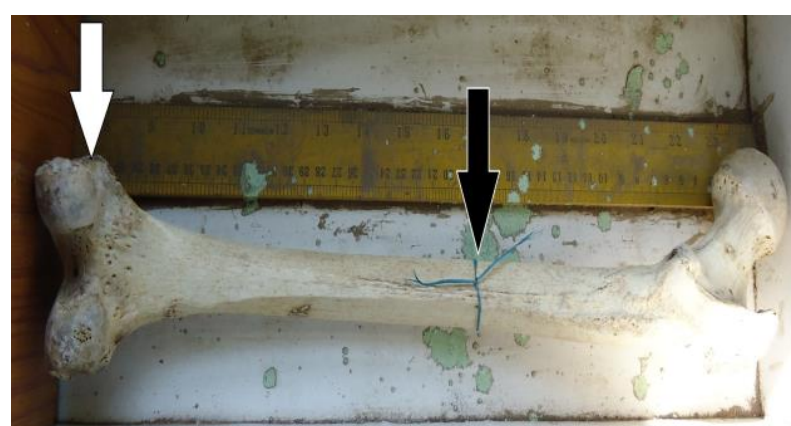

Fig-1: Osteometric board for morphometric parameters of femur

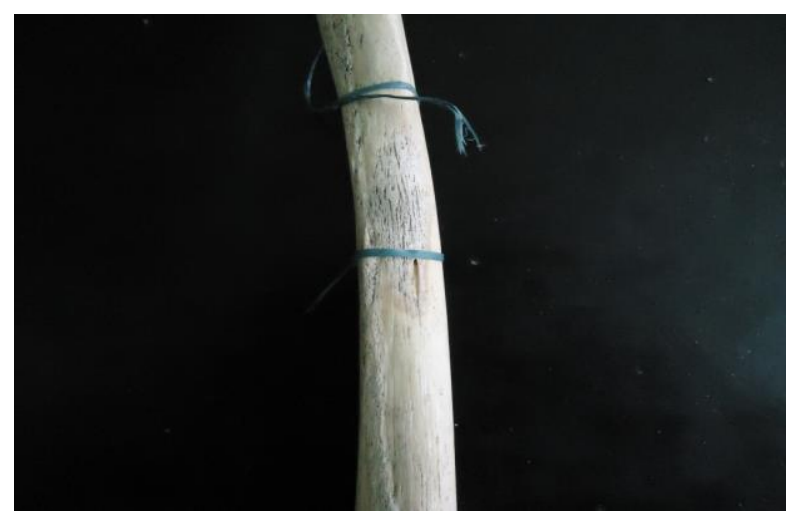

Fig-2: Double nutrient foramen

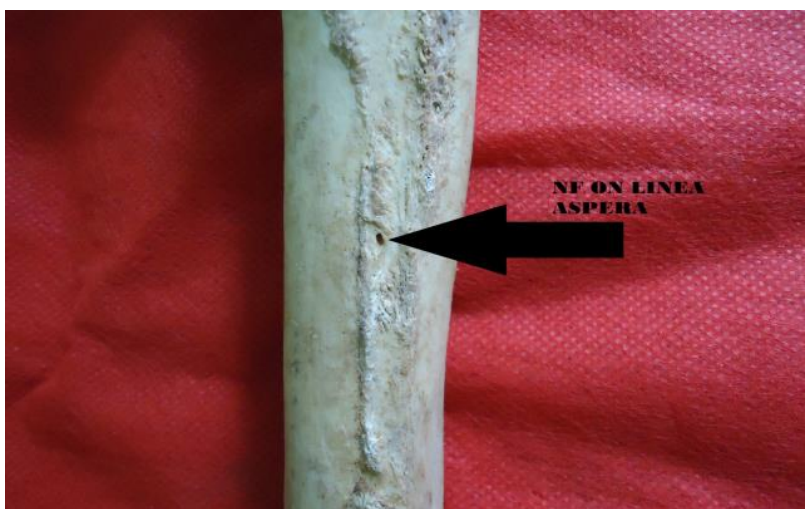

Fig-3: Nutrient foramen on linea aspera

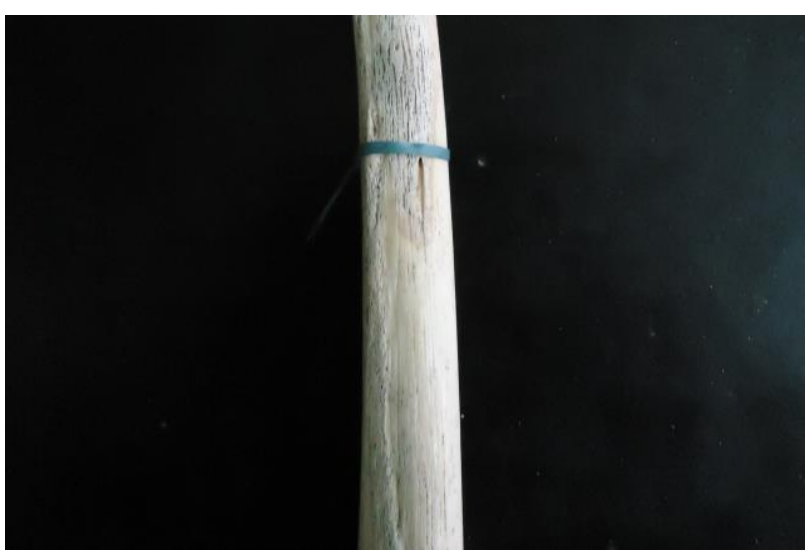

Fig-4: Nutrient foramen on lateral surface of femur

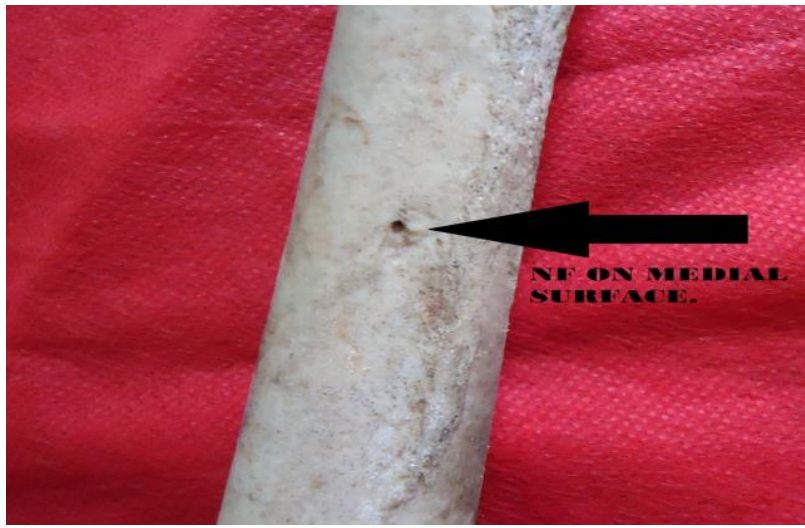

Fig-5: Nutrient foramen on medial surface of femur

\section{DISCUSSION}

The nutrient foramina of femur remained constant in position with increasing age [6]. The number, position, symmetry of the diaphyseal nutrient foramina. The nutrient foramina are restricted to the linea aspera or its immediate neighborhood in the middle third of the bone [7]. The location of the nutrient 
foramina was predominant on the posterior aspect of the lower limb long bones. The majority of the bones had a single nutrient foramen indicated the single source of blood supply to the femur [8]. The nutrient foramen of the femur was located on the linea aspera in $72.5 \%$ and $21.25 \%$ on the medial surface and $6.25 \%$ on the lateral surface of the diaphysis of the bone [9]. Nutrient foramen was found $18.66 \%$ on the medial lip of the linea aspera, $11.33 \%$ on the lateral lip of linea aspera, $27.33 \%$ were on posterior surface, $35 \%$ the rest and also observed $48(32 \%)$ were single foramen, 102 $(68 \%)$ were double foramina and foramen were absent in 2 femora[10]. The number of nutrient foramen was observed one on $53.4 \%$, two on $44.4 \%$ and three foramina on $2.2 \%$ of 410 femurs [11]. Out Of the total 150 foramina, $48 \%$ were in the proximal third and $52 \%$ in the middle third and no foramina in the distal third [12]. The location of the nutrient foramina is predominant on the posterior aspect of the lower limb long bones. The majority of the bones studied had a single nutrient foramen, which may represent a single source of blood supply [13]. Our findings are in contrast regarding number of nutrient foramen with previous literature which may be due to the parameters like size and the nutrient foramen, position of foramen lips of linea aspera in the previous study $[10,11]$ but the findings in the present study are in mere agreement with previous literature $[9,12,13]$.

\section{CONCLUSION}

The knowledge of variations in nutrient foramina is of great importance in treating the patients with trauma having long bone injuries, cases of congenital pseudoarthrosis.

\section{ACKNOWLEDGEMENT}

The authors are also grateful to authors, editors and publishers of all those articles, journals and books from where the literature for this article has been reviewed and discussed.

\section{Conflict of Interest: NIL}

\section{REFERENCES}

1. Kizilkanat, E., Boyan, N., Ozsahin, E. T., Soames, R., \& Oguz, O. (2007). Location, number and clinical significance of nutrient foramina in human long bones. Annals of Anatomy-Anatomischer Anzeiger, 189(1), 87-95.
2. Longia, G. S., Ajmani, M. L., Saxena, S. K., \& Thomas, R. J. (1980). Study of diaphyseal nutrient foramina in human long bones. Cells Tissues Organs, 107(4), 399-406.

3. Campos, F. F., Pellico, L. G., Alias, M. G., \& Fernandez-Valencia, R. (1987). A study of the nutrient foramina in human long bones. Surgical and Radiologic Anatomy, 9(3), 251-255.

4. Erika Collipal; Ramiro Vargas; Ximena Parra; Héctor Silva \& Mariano del Sol Diaphyseal Nutrient Foramina in the Femur, Tibia and Fibula Bones. Int J. MorphoL. 2007; 25(2):305-308.

5. Al-Motabagani, M. A. H. (2002). The arterial architecture of the human femoral diaphysis. $J$ Anat Soc India, 51(1), 27-31.

6. Kirschner, M. H., Menck, J., Hennerbichler, A., Gaber, O., \& Hofmann, G. O. (1998). Importance of arterial blood supply to the femur and tibia for transplantation of vascularized femoral diaphyses and knee joints. World journal of surgery, 22(8), 845-852.

7. Dillaman, R. M., Roer, R. D., \& Gay, D. M. (1991). Fluid movement in bone: theoretical and empirical. Journal of biomechanics, 24(1), 163 177.

8. Mysorekar, V. R. (1967). Diaphysial nutrient foramina in human long bones. Journal of anatomy, 101(Pt 4), 813-822.

9. Malukar, O., \& Joshi, H. (2011). Diaphysial nutrient foramina in long bones and miniature long bones. NJIRM, 2(2).

10. Kumar, R., Mandloi, R. S., Singh, A. K., Kumar, D., \& Mahato, P. (2013). Analytical and morphometric study of nutrient foramina of femur in Rohilkhand Region. Innovative Journal of Medical and Health Science, 3:52-54.

11. Lütken, P. (1950). Investigation into the position of the nutrient foramina and the direction of the vessel canals in the shafts of the humerus and femur in man. Cells Tissues Organs, 9(1-2), 57 68.

12. Malukar, O., \& Joshi H. (2011). Diaphysial Nutrient Foramina in Long Bones and Miniature Long Bones. Natl Journal Integr Research Medical, 2(2):23-26.

13. Pereira, G. A. M., Lopes, P. T. C., Santos, A. M. P. V., \& Silveira, F. H. S. (2011). Nutrient foramina in the upper and lower limb long bones: morphometric study in bones of Southern Brazilian adults. International Journal Morphol, 29(2), 514-520. 